\title{
Improving the ability of subtraction through numerical card puzzles media for students with hearing impairment
}

\author{
Fatmawati $^{1}$, Safaruddin ${ }^{2}$ \\ ${ }^{12}$ Universitas Negeri Padang
}

\begin{tabular}{l} 
Article Info \\
\hline Article history: \\
Received Oct $25^{\text {th }}, 2018$ \\
Revised Oct $27^{\text {th }}, 2018$ \\
Accepted Nov $26^{\text {th }}, 2018$ \\
\hline
\end{tabular}

Keyword:

Numerica,

Subtraction Task,

Hearing Impairment

\begin{abstract}
The purpose of this research was to reveal the effect of using numerical card puzzles and know the differences between two different variables. The design was one group pre-test posttest which control class was also experimental class. The research was conducted at class $\mathrm{V}$ with five students who have hearing impairment. The sample was chosen by using a total sampling method. The data was analyzed by using Mann Whitney with $95 \%$ and $\alpha=0.005$. The research result shows that: first, the students learning results were low when the teacher use blackboard as media. Second, student's learning results improved significantly when the teacher used numerical card puzzles. The test showed that Ucount $=25$ and Utable $=8$. Based on the test, the hypothesis is accepted with Ucount $\geq$ Utable can be concluded that numerical card puzzles is effective to improve student with hearing impairment.
\end{abstract}

(C) 2018 The Authors. Published by Redwhitepress

This is an open access article under the CC BY-NC-SA license (https://creativecommons.org/licenses/by-nc-sa/4.0/

\section{Corresponding Author:}

\section{Fatmawati}

Universitas Negeri Padang

Email: fatmawati@fip.unp.ac.id

\section{Introduction}

The importance of mathematics in daily life is seen in the application in life such as buying and selling, calculating, measuring and so on. According to Turmudi (2008: 3), mathematics is closely related to our daily life so learners will be able to apply mathematics in a useful context, both in the world of life or in the world of work later. The use of mathematics in daily life requires learners to master the basic concepts of mathematics. Placement of the basic concepts of mathematics becomes a necessity for learners. A research study by Shadiq in 2004 suggests that mathematics has a very important role, it is impossible for a person to live in this part of the world in the 20th century without using mathematics. This study supports that math is indeed very important in daily life, such as the use of subtraction.

Subtraction is one of the four basic operations of mathematics, and it is the opposite of addition operation. Subtraction operation is the basic material that learners must master in learning mathematics. Application of subtraction is widely used in daily life. In basic education, learners gain knowledge or basic knowledge of the subjects to be taught. Each level has different competencies.

In accordance with mathematics textbooks, such as for class $\mathrm{V}$ the material required for learners is related to addition, subtraction, multiplication, division and mixed count operation. Learners learn from the addition, then subtraction to multiplication and division. It is an example that the mathematics 
learning materials are always related with each other, for example, when learners are learning about division, learners have to master the subtraction, although what is required for each learner is different. Transferring material by the researcher is submitted during the teaching and learning process. Planning of the learning process must be well prepare made by a researcher so that learning can occur effectively. Some components of planning the learning process are the indicators, the purpose of learning, methods, strategies, media and assessment in learning.

Related to teaching and learning process, one of the components is instructional media. Media is a tool, means of intermediary and liaison to deliver the message. There are a lot of media types, in general, there are three-dimensional media and two-dimensional media. One example of two-dimensional media is a puzzle in the form of such an educational game. The puzzles media is also used in several studies, such as based on Sofa Shoffan research results in 2015, learning using intelligent puzzle media brings changes to learners' learning outcomes, such as improving cognitive abilities of learners in counting 1-20. In line with that the results of research by Prabowo in 2012 mentioned that the implication of the research conclusion that the use of puzzle media for teachers will improve student learning outcomes, increase student enthusiasm in learning, improve cooperation and demand teachers to be creative.

The puzzle media can be modified according to our needs such as the media of a numerical card puzzles. Numerical card puzzle is a puzzle containing numerical cards to assist learners in working on the problem of subtraction, consisting of two parts, the problem part and the completion part. This media is based on a subtraction with a short down-layered method and a long-bottomed method based on the place score. The way to use it is the students will attach a numerical card on the puzzles board in accordance with the questions given by the researchers and the solution of the problem. This media is adapted from a game that can attract learners because it has never been used by teachers. The adaptation of the numerical card puzzles media based on the material taught, is in the mathematics learning book related to the subtraction by borrowing. So, delivering material to learners will be easier. The question is then, the translation of the numerical in accordance with the place score, until there will be the process of borrowing, subtraction and even a short addition.

In the use of media also can be seen in terms of learners. Learners here are no exception learners with special needs. Learners who have special needs that require special services are also eligible for education. Participants with special needs are learners who need special services in running their daily life, including in terms of education. When learners need special services such as special media, additional methods, new strategies in learning, it aims for learners to more easily understand the material being taught. One type of learners with special needs is learners with hearing impairments or deaf.

Deaf or hearing impairment is a condition of hearing loss that causes a person cannot catch a variety of stimuli, especially through the sense of hearing (Somantri, 2007: 93). Common terms that indicate difficulty in hearing, which includes the overall difficulty of hearing from the light to the heavy, are classified into the deaf and inadequate parts. Therefore, they experience obstacles in the process of language information through hearing. The impact on life in a complex way implies that due to hearing impairment, the child's development becomes inhibited (Mega, 2012: 260). To note the consequences of hearing loss is the obstacle in communicating, while communication is very important in daily life.

Students' perception is they find difficult in learning mathematics, so learners are lazy to learn especially to repeat the material being taught. To help learners in overcoming the difficulties of learning mathematics, depends on how to convey it, learn math starting from the concrete thing to facilitate learners understand the material taught especially for the consolidation of the concept for learners. It is supported by Aini's research in 2015 shows when learning using concrete media, one of them is experience and impression in learning more attached to learners itself. The problem of the learners' difficulties in subtraction abilities must be addressed early on, especially when viewed from the importance of mathematics in life and subtraction is also from the foundation of mathematics learning. One of the components that attract learners to learn is the media of learning.

\section{Method}

This research was conducted by using one of the research approaches, quantitative approach. The type of research used is experimental research, conducting an experimental activity to examine two things compared after the treatment or experiment. Experimental research is divided into two, namely preexperiment or commonly called quasi-experiment and true-experiment. The experimental research used in this research is the type of quasi-experiment or pre-experiment research type with one group pretestposttest design. In accordance with the research design that is one group pretest-posttest design, the research will be carried out in one group, the control group into the experimental group. 
Improving the ability of subtraction through numerical card puzzles media for students with hearing impairment

This study will use two observations, the first observation is a pretest (O1), the initial test to determine the initial ability of the learner before treatment is given, then the treatment is given using numerical card puzzles media, and the second observation is post-test $(\mathrm{O} 2)$, giving test to see the learner's ability after given the treatment.

Variable in this research consists of two variables that are independent variable and dependent variable. The dependent variable in this research is the ability of subtraction operation whereas for the independent variable is the numerical card puzzles media. The operational definition of variables are also reviewed from the two variables in this study. Numericalcard puzzlesmedia used in this is media that has been modified based on subtraction material with borrowed techniques which is already taught, assisted by a numerical card as a puzzle piece. Subtraction operations ability, learners are able to place the score of the numerical in accordance with the score of place and perform the process of borrowing and subtraction.

The population in this study is all students with hearing impairment at class V in SLB WacanaAsih Padang. Arikunto (2013: 95) states when the number of population or subject of less than 100 then better taken all and this study become population research. In this study, the population used as sample research, commonly called sampling saturated or total sampling. Sampling method in this research is total sampling method, which is all students with hearing impairment at class V in SLB WacanaAsih Padang, who are five students.

In this research, the research instruments used are the subtraction problems given before and after the treatment. After that, data collection technique in this study is a test with the data collection tool is the items of the test. The test contains 10 questions about the subtraction by borrowing dozens. Data analysis on quantitative research using statistical methods, in these study data analysis techniques using statistical tests by the Mann-Whitney test formula with the significant level is $95 \%$ or $\alpha=0.05$. Hypothesis testing criterion is $\mathrm{Ha}$ accepted if Ucount $>$ Utable and Ho accepted if Ucount $\leq$ Utable.

\section{Results and Discussions}

The data has been obtained from the student with hearing impairmentat class V students in SLB WacanaAsih Padang. The material given is about the subtraction of tens with borrowing techniques. When the field is in accordance with the techniques and data collection tools, the data obtained through the writing test which consists of items about the subtraction. Each test given consists of 10 questions about subtraction. The data is processed in the form of pretest and post-test result, means to test the initial ability of the subject before the treatment is given and the final ability after being given treatment using the numerical card puzzles. After the pretest result is entered into the table, then given treatment using the numerical card puzzles media. There is an increase in the students' evaluation score so final test or posttest can be given. The scores of pretest and post-test will be entered into the table, shown in the table below, for $\mathrm{O} 1$ is the pretest score and $\mathrm{O} 2$ is the post-test scores.

Table1. Pre-test and Post-test scores

\begin{tabular}{llll}
\hline No & Students's name & O1 & O2 \\
\hline $\mathbf{1}$ & GL & 0 & $\mathbf{8 0}$ \\
2 & TR & 0 & $\mathbf{7 0}$ \\
3 & ST & 0 & $\mathbf{6 0}$ \\
$\mathbf{4}$ & JW & 0 & $\mathbf{8 0}$ \\
\hline $\mathbf{5}$ & RT & $\mathbf{0}$ & $\mathbf{7 0}$ \\
\hline
\end{tabular}

It has been clearly seen the pretest and post-test scores in the table. The scores contained in the table above are the score of the hearing-impaired learners for the ability in subtracting tens with borrowing techniques. Next, the score will be sorted from the highest to the lowest score. After sorting, it will be ranked on each score from the highest to the lowest. The result will be seen like table 2 below, the pretest and post-test scores and rank of each score

Table2. Dataanalysis Rank. 


\begin{tabular}{cccc}
\hline No & Students' name & Score & Rank \\
\hline $\mathbf{1}$ & GL & 80 & $\mathbf{1 , 5}$ \\
$\mathbf{2}$ & JW & 80 & $\mathbf{1 , 5}$ \\
$\mathbf{3}$ & TR & 70 & $\mathbf{3 , 5}$ \\
$\mathbf{4}$ & RT & 70 & $\mathbf{3 , 5}$ \\
$\mathbf{5}$ & ST & 60 & $\mathbf{5}$ \\
$\mathbf{6}$ & GL & 0 & $\mathbf{8}$ \\
$\mathbf{7}$ & TR & 0 & $\mathbf{8}$ \\
$\mathbf{8}$ & ST & 0 & $\mathbf{8}$ \\
$\mathbf{9}$ & JW & 0 & $\mathbf{8}$ \\
\hline $\mathbf{1 0}$ & RT & $\mathbf{0}$ & $\mathbf{8}$ \\
\hline
\end{tabular}

The next activity after getting their respective rankings, rank them on the pretest results and rank on the post-test results. Seen in the table below, summed according to the section for the pretest and the section for the post-test. The pretest and post-test scores are followed by their respective ranks, and the sum of the rankings is ranked in the pretest score and the rank at the post-test score

Table 3.Rank Calculation

\begin{tabular}{cccccc}
\hline No & $\begin{array}{l}\text { Students' } \\
\text { name }\end{array}$ & O1 & O2 & R1 & R2 \\
\hline $\mathbf{1}$ & GL & 0 & 80 & 8 & $\mathbf{1 , 5}$ \\
$\mathbf{2}$ & TR & 0 & 70 & 8 & $\mathbf{3 , 5}$ \\
$\mathbf{3}$ & ST & 0 & 60 & 8 & $\mathbf{5}$ \\
$\mathbf{4}$ & JW & 0 & 80 & 8 & $\mathbf{1 , 5}$ \\
$\mathbf{5}$ & RT & 0 & 70 & 8 & $\mathbf{3 , 5}$ \\
\hline Total & & & & $\mathbf{4 0}$ & $\mathbf{1 5}$ \\
\hline
\end{tabular}

\begin{tabular}{|c|c|}
\hline Note & \\
\hline $\mathrm{O} 1$ & $=$ pretest result \\
\hline $\mathrm{O}_{2}$ & $=$ post-test result \\
\hline $\mathrm{R} 1$ & $=$ Ranking of pretest results \\
\hline 0 & $=$ Ranking of post-test results \\
\hline
\end{tabular}

The rank calculation or rank data on the pretest and post-test results has been obtained. So all the data required in this study has been obtained in summary as below:

$\begin{array}{ll}\mathrm{R} 1 & =40 \\ \mathrm{R} 2 & =15 \\ \mathrm{n} 1 & =5 \\ \mathrm{n} 2 & =5\end{array}$

So, using mann-whitney test formula to process the data. In accordance with the input formula of each component of data required. From the calculation results, obtained Ucount $=25$ taken from the smallest count, then adjusted with Utable at a significant level of $95 \%$ and $\alpha=0.05$ ie $=8$. So the results obtained are Ucount $=25$ and Utable $=8$. The results of hypothesis testing with Ucount $=25$ and Utable $=8$ it is found that Ucount $>\mathrm{UTable}$, it indicates $\mathrm{Ha}$ is accepted and Ho is rejected. The result of this research is the numerical card puzzles media effective in increasing the subtraction's ability for the student with hearing impairmentat V class in SLB WacanaAsih Padang.

\section{Conclusion}

Based on the results of this research, the numerical card puzzles media is effective in improving the subtraction skills for student with hearing impairment of class V in SLB WacanaAsih Padang. This has been shown in the calculation of the data treated using the Mann Whitney test formula with the result 
Improving the ability of subtraction through numerical card puzzles media for students with hearing impairment

Ucount $=49$ taken from the smallest count value and Utable $=8$ adjusted with a significant level $95 \%$ and $\alpha=0.005$. Shows Ucount $>$ Utable with Ucount $=49>$ Utable $=8$. This research shows, firstly, when not using the media of a numeric card puzzles, the value of the reduction ability test by borrowing technique of the learner is still low. Secondly, when assisted using a numerical card puzzles media, the value of the reduction of ability test with the technique of borrowing students has increased. In accordance with the results of hypothesis testing then $\mathrm{Ha}$ will be accepted if Ucount>Utable and can be concluded that $\mathrm{Ha}$ received with the numerical card puzzlesare effective in improving the subtraction ability for the student with hearing impairmentof class V in SLB WacanaAsih Padang.

\section{References}

Ismail,A.(2009). Education Games.Yogyakarta: Pro-U Media.

Lestari, Ni Komang AyuSri., Raga, Gede., Sudatha, Ghe Wawan. (2014). Penerapan Metode Bermain Berbantuan Media Puzzle Angka Untuk Meningkatkan Kemampuan Kognitif Dalam Pengenalan Bilangan. Jurnal PGPAUD Universitas Ganesha (Volume2 Nomor1).2-3.

Mega Silvia Dewi. (2012) Penggunaan Aplikasi Adobe Photoshop dalam Meningkatkan Keterampilan Editing Foto Bagi AnakTunarungu. Jurnal IlmiahPendidikan Khusus (Volume 1 Nomor 2) 260-270

Miftah,M.(2013).Fungsi dan Peran Media Pembelajaran Sebagai Upaya Peningkatan Kemampuan Belajar Siswa. Jurnal KWANGSAN (Volume1Nomor2).100.

Prabowo,Rendra Ari.(2012). Penggunaan Media Puzzle Untuk Meningkatkan Hasil Belajar Pada Mata Pelajaran IPA di Kelas V SDN1 Jatipurwo. Skripsi Tidak diTerbitkan. Universitas Muhammadiyah Surakarta.

Rahayu.L.(2010). 20 Fun Activitis For Toddler. Surakarta: Indiva Media Kreasi.

Runtukahu,Tombokan J.\&SelpiusKandou. (2014). Pembelajaran Matematika Dasar Bagi Anak Berkesulitan Belajar.Yogyakarta:Ar-RuzzMedia.

Shadiq,F.(2004). Pemecahan Masalah Penalaran dan Komunikasi. Yogyakarta: PPPG Matematika.

Sofa,S.(2015).Penerapan Media Puzzle Cerdas Untuk Meningkatkan Kemampuan Kognitif Anak Taman Kanak-Kanak dalam Berhitung. Jurnal Pedagogi (Volume1 Nomor1)

Somantri, Sutijahati. 2007. Psikologi Anak Luar Biasa. Bandung: Refika Aditama.

Sukayati,(2011). Pembelajaran Pecahan di Sekolah Dasar.Yogyakarta: Widyaiswara PPPPTK Matematika.

Turmudi.(2008). Landasan Filsafat dan Teori Pembelajaran Matematika (Berparadigma Eksploratif dan Investigatif). Jakarta:Leusur Cita Pustaka.

Widyarahyu, G \& Nursida. (2016). Mengembangkan pembelajaran Matematika dengan Metode Permainan Untuk Siswa kelas 1 MI. Jurnal Pendidikan dan Pendidikan Matematika (Volume5 Nomor2). 128.

Yamin,M. (2005). Strategi Pembelajaran Berbasis Kompetensi. Jakarta: Gaung Persada. 